\title{
ANALISIS PENDAPATAN DAN TINGKAT KEUNTUNGAN USAHA TAHU TEMPE DI DESA BATU TIMBAU KABUPATEN KUTAI TIMUR
}

\author{
Rusmiyati ${ }^{*}$, Felya Rindiani ${ }^{2}$, Istikomah ${ }^{3}$ \\ 1,2 3 Sekolah Tinggi Pertanian Kutai Timur, jl. Soekarno Hatta No. 1 Sangatta Utara, \\ Kutai Timur, Kalimantan Timur \\ *Email:rusmiyati@stiperkutim.ac.id
}

Naskah diterima: 2 Juli 2021 Direvisi: 22 Juli 2021 Disetujui terbit: 29 Agustus 2021

\begin{abstract}
Analysis of Income and Profit Level of Tofu and Tempe Business in Batu Timbau Village, East Kutai Regency. The purpose of this study was to determine the income and level of profit obtained by the tofu and tempeh business in Batu Timbau Village. This research was conducted from March to May 2020. The sampling method used in this study was a saturated sample with 2 entrepreneurs as respondents. Data were analyzed to obtain total costs, revenues and revenues as well as profit levels. The results of the study showed that the average income of tofu and tempe entrepreneurs in Batu Timbau Village was Rp. 13,084,298,61/month with a profit rate of 1.8 .
\end{abstract}

Keywords: Tofu, Tempe, income, profits.

\section{ABSTRAK}

Analisis Pendapatan dan Tingkat Keuntungan Usaha Tahu dan Tempe di Desa Batu Timbau Kababupaten Kutai Timur. Tujuan penelitian ini adalah untuk mengetahui pendapatan dan tingkat keuntungan yang diperoleh usaha tahu dan tempe yang ada di Desa Batu Timbau. Penelitian ini dilakukan pada bulan Maret hingga Mei 2020. Metode pengambilan sampel yang digunakan dalam penelitian adalah sampel jenuh dengan jumlah responden 2 orang pengusaha. Data dianalisis untuk memperoleh biaya total, penerimaan dan pendapatan serta serta tingkat keuntungan. Hasil pada penelitian menunjukkan bahwa rata-rata pendapatan pengusaha tahu dan tempe di Desa Batu Timbau sebesar Rp.13.084.298,61/bulan dengan tingkat keuntungan sebesar 1,8 .

Kata kunci: Tahu, Tempe, Pendapatan, Tingkat Keuntungan

\section{PENDAHULUAN}

Tahu dan tempe sudah menyatu dengan kuliner Indonesia. Keduanya juga dikonsumsi oleh berbagai golongan masyarakat karena merupakan sumber protein nabati yang baik dan juga harganya yang terjangkau (https://hellosehat.com/nutrisi/faktagizi/tahudan-tempe-nutrisi). Tahu dan tempe sudah akrab dilidah orang Indonesia sejak lama. Makanan hasil variasi olahan kacang kedelai ini pun menjadi makanan yang populer karena harganya yang relatif terjangkau untuk dikonsumsi masyarakat dari berbagai lapisan, mulai dari masyarakat kelas bawah, masyarakat kelas menengah, hingga masyarakat kelas atas. Bahkan seperti diberitakan, 
tahu dan tempe mulai digemari beberapa negara tetangga seperti Malaysia, Jepang, dan lain-lain karena rasanya yang nikmat serta bergizi tinggi (Ambara, dkk., 2017).

Pembuatan tempe dan tahu merupakan industri rakyat sehingga hampir setiap orang dapat dikatakan mampu membuat tempe dan tahu sendiri. Perbedaan yang paling jelas antara produksi tahu dan tempe adalah untuk memproduksi tempe diperlukan modal empat kali lebih besar dari biaya operasional produksi tahu (Anzitha, 2019). Menurut Undang-Undang No 3 Tahun 2014 tentang perindustrian yang disebut industri adalah seluruh bentuk kegiatan ekonomi yang mengolah bahan baku dan memanfaatkan sumber daya industri sehingga menghasilkan barang yang mempunyai nilai tambah atau manfaat lebih tinggi, termasuk jasa industri.

Usaha industri tempe yang berkembang dimasyarakat adalah industri rumah tangga dan industri kecil. Permasalahan pokok industri kecil adalah modal kerja yang sangat minim, kenaikan harga bahan baku, pemasaran untuk menyalurkan tempe ke konsumen, karena kurangnya informasi pasar terkait dengan pola permintaan konsumen (Simatupang, 2019). Usaha pembuatan tempe sangat menguntungkan. Produk tempe sangat digemari oleh masyarakat, tempe merupakan salah satu makanan tradisional yang populer (Hairun dkk, 2016). Kebutuhan konsumen yang semakin meningkat seiring dengan harga-harga kebutuhan pangan yang semakin melambung, maka pengembangan Industri tempe sangat penting dalam rangka memenuhi kebutuhan konsumen. Keberadaan industri tempe harus tetap dipertahankan dan tetap hidup serta perlu dikembangkan untuk memenuhi kebutuhan konsumen yang semakin meningkat (Amelia, 2018).

Pengembangan agroindustri diharapkan mampu menyerap hasil pertanian dari petani. Hasil pertanian yang masih berupa produk primer akan diolah menjadi produk sekunder atau tersier sehingga akan menghasilkan nilai tambah. Nilai tambah suatu produk sangat penting untuk meningkatkan harga jual produk tersebut (Lestari dkk, 2019).

Industri tahu merupakan industri rumahan. Bahan utama pembuatan tahu adalah kedelai yang diproses melalui produksi hingga menghasilkan ouput berupa tahu. Industri tahu dapat memberikan nilai tambah terhadap komoditas kedelai (Rosita dkk, 2019). 
Pengaruh terbesar pada industri tempe adalah peningkatan harga kedelai impor. Meningkatnya harga kedelai akan mengakibatkan biaya faktor-faktor produksi meningkat dan berdampak pada hasil pendapatan pengusaha tempe (Naelis dan Novindra, 2015).

Pengolahan kedelai menjadi tempe mampu menciptakan nilai rasa yang disukai banya orang. Tempe telah dikonsumsi oleh masyarakat Indonesia sejak lama. Industri tempe mampu menyerap sejumlah tenaga kerja baik yang terkait secara langsung dalam proses produksi maupun yang terkait dengan perdagangan masukan dan keluaran industri pengolahan (Amang dalam Wahyuni, 2017). Pengusaha tempe tahu sebagai kegiatan yang mampu memberikan penghasilan bagi keluarga yang secara tidak langsung merupakan sumbangan bagi perekonomian setempat (Djumadil, 2018).

Terdapat beberapa usaha di bidang home industry tempe di Desa Batu Timbau Kecamatan Batu Ampar. Rata-rata masyarakat Desa Batu Timbau gemar mengkonsumsi tahu dan tempe, dari golongan umur muda hingga golongan umur tua. Tahu dan tempe merupakan makan tradisional yang populer, selain rasanya yang enak, harganya murah dan terjangkau serta memiliki nilai gizi yang tinggi. Tahu dan tempe merupakan makanan sumber protein yang baik dan murah harganya dibandingkan dengan sumber protein hewani seperti daging, susu dan telur. Tahu adalah makanan yang baik dikonsumsi oleh semua golongan umur dengan kandungan protein yang cukup tinggi. Tempe kaya akan serat pangan, kalsium, vitamin B dan zat besi.

Permasalaan yang dapat dikemukakan yaitu berapakah pendapatan dan tingkat keuntungan usaha tahu dan tempe di Desa Batu Timbau Kecamatan Batu Ampar Kabupaten Kutai Timur. Tujuan penelitian ini adalah untuk mengetahui pendapatan dan tingkat keuntungan usaha tahu dan tempe di Desa Batu Timbau kecamatan Batu Ampar Kabupaten Kutai Timur.

\section{METODE PENELITIAN}

Penelitian ini dilaksanakan selama tiga bulan yaitu bulan Maret sampai dengan Mei 2020 di Kelurahan Batu Timbau Kecamatan Batu Ampar Kabupaten Kutai Timur Provinsi Kalimantan Timur. Penelitian ini menggunakan data primer dan data sekunder. Teknik yang digunakan dalam pemperoleh data primer ada;ah melalui observasi dan wawancara. Data 
sekunder diperoleh dari literatur dan dari instansi terkait seperti Kantor Desa Batu Timbau, BPS Kutai Timur dan Kutai Timur Dalam Angka 2015-2017.

Populasi dalam penelitian ini adalah pengusaha tahu dan tempe di Desa Batu Timbau Kecamatan Batu Ampar, berdasarkan fakta yang ada dilapangan jumlah populasi pengusaha tahu dan tempe berjumlah 2 orang pengusaha, dan seluruh populasi dijadikan sampel, sehingga sampel yang digunakan yaitu sampel jenuh. Sampling jenuh adalah teknik sampling. bila semua anggota populasi dijadikan sampel (Sugiyono, 2012). Penentuan lokasi penelitian dilakukan secara purpossive berdasarkan produksi yang terus menerus walaupun saat kenaikan harga kedele, yaitu Desa Batu Timbau Kecamatan Batu Ampar.

1. Analisis Biaya

Biaya yang diperlukan untuk memproduksi tahu dan tempe terdiri atas total biaya variabel (TVC) dan total biaya tetap (TFC). Berikut ini adalah rumus total biaya menurut Sukirno (2003):

$\mathrm{TC}=\mathrm{TFC}+\mathrm{TVC}$

Keterangan:

$\mathrm{TC}=$ Total Cost $($ Total Biaya)

TFC $=$ Total Fixed Cost (Total Biaya

Tetap)
TVC $=$ Total Variable Cost $($ Total Biaya Variabel)

a. Biaya tetap

Biaya tetap adalah biaya yang jumlah totalnya tetap tidak berubah untuk satu periode waktu tertentu. Biaya ini tidak naik turun meskipun volume kegiatannya bervariasi. Biaya tetap dalam hal ini berasal dari penyusutan alat produksi. Berikut adalah rumus penyusutan menurut Sukirno (2003):

$$
\text { Penyusutan }=\text { Harga Perolehan }-
$$

Nilai Residu

\section{Umur Ekonomis}

b. Biaya Variabel

Biaya variabel (variable cost), yaitu biaya yang jumlahnya bervariasi secara proporsional dengan volume kegiatan. Biaya variabel meliputi bahan baku, upah tenaga kerja, dan bahan bahan bakar.

\section{Analisis Penerimaan}

Total Revenue (TR) atau total penerimaan adalah jumlah seluruh penerimaan hasil produksi yang diperoleh dari hasil perkalian antara jumlah produksi (Q) dengan harga jual (P). Total penerimaan dapat diperoleh dengan menggunakan rumus Suratiyah (2015):

$$
\mathrm{TR}=\mathrm{P} X \mathrm{Q}
$$

Keterangan:

TR = Total Revenue (Total Penerimaan)

$\mathrm{P}=$ Price (Harga)

$\mathrm{Q}=$ Quantity (Jumlah Produksi) 


\section{Menghitung pendapatan}

Pendapatan dapat diperoleh dengan mengurangkan penerimaan (TR) dengan biaya total (TC). Rumus pendapatan adalah sebagai berikut:

$$
\mathrm{I}=\mathrm{TR}-\mathrm{TC}
$$

Keterangan:

I = Pendapatan

$\mathrm{TR}=$ Penerimaan Total

$\mathrm{TC}=$ Biaya Total

\section{Menghitung Tingkat Keuntungan}

Tingkat Keuntungan merupakan perbandingan antara penerimaan dengan biaya total. Menurut Suratiyah (2015), bahwa tingkat keuntungan dapat diperoleh dengan rumus berikut:

$$
R / C=\frac{T R}{T C}
$$

Keterangan:

Total Penerimaan (TR)

Total Biaya (TC)

Kriteria penilaian tingkat keuntungan:

1. $R / C>1$ artinya usaha layak

2. $\mathrm{R} / \mathrm{C}=1$ artinya usaha impas

3. $\mathrm{R} / \mathrm{C}<1$ artinya usaha tersebut tidak layak

HASIL DAN PEMBAHASAN

\section{Biaya Produksi Usaha Tahu dan Tempe}

Semua pengeluaran yang harus dikeluarkan untuk suatu proses produksi yang dinyatakan dengan satuan uang menurut harga pasar yang berlaku disebut biaya. Biaya yang dikeluarkan untuk membuat sejumlah barang dalam satu kali produksi disebut biaya produksi. Biaya produksi dipengaruhi jumlah barang yang diproduksi. Biaya dapat digolongkan atas biaya variabel dan biaya tetap.

\section{a. Biaya Tetap}

Biaya yang jumlahnya tetap meskipun volume produksi perusahan berubah disebut biaya tetap. Adapun biaya tetap dalam memproduksi tempe meliputi biaya untuk peralatan dan penyusutan mesin tahu dan tempe.

Berikut adalah biaya tetap usaha tahu dan tempe di Desa Batu Timbau. Perhitungan biaya penyusutan mesin dan peralatan usaha dapat dilihat pada Tabel 1 yaitu sebesar Rp 146.201,39 per bulan per pengusaha. Usaha tahu dan tempe ini masih menggunakan cara tradisional, hal ini dikarenakan kurangnya pengetahuan dalam penggunaan teknologi modern. Menurut pemilik usaha, jika menggunakan cara modern dibandingkan dengan cara tradisional akan berbeda cita rasa pada tahu dan tempe tersebut. Tekstur dan kualitas tahu dan tempe juga berbeda. Selain itu, karena terbiasa dengan penggunaan cara tradisional pemilik usaha terus mempertahankan proses produksi secara tradisional tersebut, maka perlu ditingkatkan pengetahuan dan wawasan tentang teknologi modern agar produksi yang dibuat secara modern cita rasa dan teksturnya sama seperti cara tradisional 
Tabel 1. Biaya Tetap Usaha Tahu dan Tempe di Desa Batu Timbau

\begin{tabular}{|c|c|c|c|c|}
\hline \multirow[t]{2}{*}{ No } & \multirow[t]{2}{*}{ Jenis } & Mekar Sari & Mekar Lestari & \multirow{2}{*}{$\begin{array}{l}\text { Total Biaya Tetap } \\
(\mathrm{Rp} / \mathrm{bln})\end{array}$} \\
\hline & & $\begin{array}{c}\text { Penyusutan } \\
\text { (Rp/bln) }\end{array}$ & $\begin{array}{c}\text { Penyusutan } \\
(\mathrm{Rp} / \mathrm{bln})\end{array}$ & \\
\hline 1 & Mesin Penggiling & $76.666,66$ & $72.222,22$ & $148.888,88$ \\
\hline 2 & Ember kecil & $2.500,00$ & $2.500,00$ & $5.000,00$ \\
\hline 3 & Ember besar & $6.250,00$ & $6.250,00$ & $12.500,00$ \\
\hline 4 & Baskom & $5.000,00$ & $27.500,00$ & $32.500,00$ \\
\hline 5 & Gayung & $1.500,00$ & $1.666,67$ & $3.166,67$ \\
\hline 6 & Drum & $1.388,89$ & $2.777,78$ & $4.166,67$ \\
\hline 7 & Cetakan tahu & $2.083,33$ & $2.083,33$ & $4.166,66$ \\
\hline 8 & Kain $(1 \mathrm{~m} \times 1 \mathrm{~m})$ & $1.250,00$ & $1.250,00$ & $2.500,00$ \\
\hline 9 & Pisau & 416,67 & 416,67 & 833,34 \\
\hline 0 & Keranjang & $5.000,00$ & $17.500,00$ & $22.500,00$ \\
\hline 11 & Tungku & 833,33 & 625 & $1.458,33$ \\
\hline 12 & Gentong & $3.055,56$ & $3.194,44$ & $6.250,00$ \\
\hline 13 & Jerigen besar & $2.638,89$ & & $2.638,89$ \\
\hline \multirow[t]{2}{*}{14} & Mesin Diesel & $23.611,11$ & $22.222,22$ & $45.833,33$ \\
\hline & Total & $132.194,44$ & $160.208,33$ & $292.402,77$ \\
\hline \multicolumn{2}{|c|}{ Rata-rata /bulan/ pengusaha } & & & $146.201,39$ \\
\hline
\end{tabular}

(Sumber: Data primer diolah 2020)

\section{b. Biaya Variabel}

Biaya variabel adalah biaya yang selalu berubah secara sebanding dengan volume produksi usaha. Berikut adalah biaya variabel yang dikeluarkan untuk bahan baku memproduksi tahu dan tempe. Tabel 2 menjelaskan mengenai penggunaan biaya variabel pada proses produksi usaha tahu dan tempe pada bulan April-Mei 2020. Biaya variabel usaha tahu dan tempe terdiri dari kedelai sebagai bahan baku utama serta bahan penunjang lainnya seperti ragi, bibit, bahan bakar bensin, bahan bakar solar, biaya kemasan, tenaga kerja, kayu bakar, air, listrik, transportasi dan sewa rumah. Penggunaan biaya variabel pada bahan baku kedelai sangat besar. Hal ini dikarenakan tingginya harga kedelai dipasaran, karena kedelai yang digunakan merupakan kedelai impor. Kestabilan harga kedelai dipasaran juga mempengaruhi tingkat harga serta kurangnya pemasok untuk kedelai lokal. Air yang digunakan untuk proses produksi menggunakan air PDAM yang sebelumnya sudah diendapkan. Adapun bibit tahu yang digunakan juga dibeli secara impor. Biaya variabel usaha tahu dan tempe bulan April- Mei 2020. 
Tabel 2. Biaya Variabel Usaha Tahu dan Tempe Bulan April-Mei 2020

\begin{tabular}{|c|c|c|c|c|}
\hline \multirow[t]{2}{*}{ No } & \multirow[t]{2}{*}{ Jenis } & Mekar Lestari & Mekar Sari & \multirow{2}{*}{$\begin{array}{l}\text { Total Biaya } \\
\text { Variabel } \\
\text { (Rp/2 bln })\end{array}$} \\
\hline & & $\begin{array}{l}\text { Biaya variabel } \\
\text { (Rp/2 bln) }\end{array}$ & $\begin{array}{l}\text { Biaya variable } \\
\text { (Rp/2 bln) }\end{array}$ & \\
\hline 1 & Kedelai & $26.320 .000,00$ & $15.040 .000,00$ & $41.360 .000,00$ \\
\hline 2 & Ragi & $160.000,00$ & $80.000,00$ & $240.000,00$ \\
\hline 3 & Bensin & $580.000,00$ & $400.000,00$ & $980.000,00$ \\
\hline 4 & Solar & $96.000,00$ & $80.000,00$ & $176.000,00$ \\
\hline 5 & Bibit & $210.000,00$ & $210.000,00$ & $420.000,00$ \\
\hline 6 & $\begin{array}{l}\text { Plastik } \\
\text { kemasan Kecil }\end{array}$ & $630.000,00$ & $390.000,00$ & $1.020 .000,00$ \\
\hline 7 & $\begin{array}{l}\text { Plastik } \\
\text { kemasan Besar }\end{array}$ & $1.785 .000,00$ & $1.105 .000,00$ & $2.890 .000,00$ \\
\hline 8 & Tenaga Kerja & $6.000 .000,00$ & $6.000 .000,00$ & $12.000 .000,00$ \\
\hline 9 & Kayu bakar & $500.000,00$ & $300.000,00$ & $800.000,00$ \\
\hline 10 & Air & $1.000 .000,00$ & $600.000,00$ & $1.600 .000,00$ \\
\hline 11 & Listrik & $300.000,00$ & $200.000,00$ & $500.000,00$ \\
\hline 12 & Transportasi & $100.000,00$ & $100.000,00$ & $200.000,00$ \\
\hline \multirow[t]{3}{*}{13} & Sewa rumah & $500.000,00$ & $600.000,00$ & $1.100 .000,00$ \\
\hline & Total & $38.181 .000,00$ & $25.105 .000,00$ & $63.286 .000,00$ \\
\hline & Perbulan & $19.090 .500,00$ & $12.552 .500,00$ & $31.643 .000,00$ \\
\hline \multicolumn{3}{|c|}{ Rata-rata/bulan/ pengusaha } & & $15.821 .500,00$ \\
\hline
\end{tabular}

Kayu bakar digunakan sebagai bahan bakar untuk memasak kedelai yang akan diolah menjadi tempe dan merebus sari kedelai untuk dijadikan tahu. Bahan bakar solar digunakan untuk menghidupkan kayu bakar yang akan digunakan untuk merebus kedelai dan sari kedelai, serta digunakan sebagai bahan bakar mesin diesel. Biaya air lebih besar dari pada biaya listrik dikarenakan pengusaha menggunakan air PDAM bukan air dari sungai secara langsung. Pengusaha tidak mengeluarkan biaya transportasi terlalu besar karena untuk pembelian bahan baku dan penunjangnya pengusaha hanya menitip dengan orang dan sudah dibawakan sampai rumah pengusaha. Berdasarkan perhitungan yang dilakukan diperoleh biaya variabel sebesar Rp.15.821.500,00 per bulan per pengusaha.

Berdasarkan analisis biaya, maka dapat dilihat bahya biaya bahan baku mencapai 65,35\%, sedangkan hasil penelitian Anggraini dkk (2016) bahwa biaya bahan baku mencapai 58,88\% dan Soehyono dkk (2014) biaya bahan baku mencapai 78,85\%. Sehingga dapat dikatakan bahwa biaya tertinggi dalam 
produksi tempe tahu adalah biaya bahan baku.

\section{c. Analisis Total Biaya}

Biaya total merupakan jumlah keseluruhan dari semua biaya yang digunakan dalam proses produksi.
Untuk mengetahui total biaya produksi pada usaha tahu dan tempe dengan menjumlahkan biaya tetap dan biaya variabel. Biaya tetap dalam hal ini adalah biaya penyusutan peralatan pembuatan tahu dan tempe.

Tabel 3. Total Biaya Produksi Usaha Tahu dan Tempe di Desa Batu Timbau

\begin{tabular}{ccc}
\hline $\begin{array}{c}\text { Biaya Tetap } \\
(\mathrm{Rp} / \text { bulan/pengusaha })\end{array}$ & $\begin{array}{c}\text { Biaya Variabel } \\
(\mathrm{Rp} / \text { bulan/pengusaha })\end{array}$ & $\begin{array}{c}\text { Biaya Total } \\
(\mathrm{Rp} / \text { bulan/pengusaha })\end{array}$ \\
\hline $146.201,39$ & $15.821 .500,00$ & $15.967 .701,39$ \\
\hline
\end{tabular}

Sumber: Data primer (diolah) 2020

Penggunaan biaya produksi tahu dan tempe sebesar Rp.15.967.701,39 perbulan, dengan total biaya tetap Rp.146.201,39/bulan dan total biaya variabel sebesar Rp.15.821.500,00/bulan. Penerimaan

Penerimaan usaha merupakan hasil kali antara produksi yang dihasilkan dengan harga jual. Tabel 4 berikut menjelaskan jumlah penerimaan usaha tahu dan tempe di Desa Batu Timbau adalah Rp.29.052.000,00/bulan.
Harga yang ditawarkan Mekar Lestari dan Mekar Sari sama kepada konsumen yaitu tahu Rp.1.000/potong dan tempe Rp.4.000/bungkusnya. Pada saat harga kedelai naik harga perpotong tahu dan perbungkus tempe tetap. Menurut kedua pemilik usaha harga yang ditawarkan sudah sesuai standar. Pengusaha tidak rugi dan konsumen dari semua kalangan bisa mengkonsumsi tahu dan tempe.

Tabel 4. Penerimaan Usaha Tahu dan Tempe di Desa Batu Timbau

\begin{tabular}{|c|c|c|c|}
\hline \multirow[t]{2}{*}{ Nama usaha } & \multicolumn{2}{|c|}{ Penerimaan $(\mathrm{Rp} / 2 \mathrm{bl}$} & \multirow{2}{*}{$\begin{array}{l}\text { [otal Penerimaan } \\
\text { (Rp/2 bulan) }\end{array}$} \\
\hline & Tahu & Tempe & \\
\hline Mekar Lestari & $35.496 .000,00$ & $41.760 .000,00$ & $77.256 .000,00$ \\
\hline Mekar Sari & $13.872 .000,00$ & $25.080 .000,00$ & $38.952 .000,00$ \\
\hline Total & $49.368 .000,00$ & $66.840 .000,00$ & $16.208 .000,00$ \\
\hline Perbulan & $24.684 .000,00$ & $33.420 .000,00$ & $8.104 .000,00$ \\
\hline Rata-rata/bulan/ pengusaha & & & $29.052 .000,00$ \\
\hline
\end{tabular}

Sumber: Data primer (diolah) 2020

Tabel 5. Pendapatan Usaha Tahu dan Tempe

\begin{tabular}{ccc}
\hline $\begin{array}{c}\text { Penerimaan } \\
(\mathrm{Rp} / \text { bulan })\end{array}$ & $\begin{array}{c}\text { Biaya produksi } \\
(\mathrm{Rp} / \text { bulan) }\end{array}$ & $\begin{array}{c}\text { Pendapatan } \\
(\mathrm{Rp} / \text { bulan })\end{array}$ \\
\hline $29.052 .000,00$ & $15.967 .701,39$ & $13.084 .298,61$ \\
\hline
\end{tabular}

Sumber: Data primer (diolah) 2020 
Pendapatan

Pendapatan usaha tahu dan tempe merupakan hasil pengurangan antara Penerimaan dengan jumlah biaya produksi. Biaya produksi terdiri atas biaya tetap dan biaya variabel. Biaya tetap merupakan nilai penyusutan peralatan. Tabel 5 menunjukkan pendapatan yang diterima oleh pengusaha tahu dan tempe di Desa Batu Timbau setiap bulan.

Pada perhitungan sebelumnya diketahui total penerimaan yang diperoleh oleh pengusaha tahu dan tempe yaitu Rp.29.052.000,00/bulan. Penerimaan diperoleh dari harga jual dikali dengan banyaknya hasil produksi dari tahu dan tempe, sedangkan total biaya produksi diperoleh dari penjumlahan penyusutan biaya tetap dengan biaya variabel Rp.15.967.701,39/bulan. Jadi pendapatan usaha tahu dan tempe yang diperoleh sebesar Rp.
13.084.298,61 per bulan. Jadi pendapatan usaha tahu dan tempe dari penelitian ini diperoleh sebesar Rp.13.084.298,61/bulan, sedangkan penelitian Rondonuwu dan Sulaeman (2018) pendapatan yang diperoleh Rp.21.989.129,23/bulan, dapat dikatakan bahwa semakin banyak memproduksi maka semakin besar pendapatan yang akan diperoleh pengusaha. Melihat Prosentase pendapatan terhadap penerimaan, maka memiliki prosentase sebesar $45 \%$, sedangkan hasil penelitian Santoso sebesar 18\% dan Sedana $32,88 \%$.

Tingkat keuntungan

Berdasarkan kriteria nilai R/C rasio, maka suatu usaha dinilai menguntungkan jika nilai $\mathrm{R} / \mathrm{C}$ ratio > 1, dengan demikian penerimaan lebih besar dari biaya yang dikeluarkan. Berikut Tabel 8 menunjukkan hasil perhitungan tingkat keuntungan.

Tabel 8. Nilai R/C ratio Usaha Tahu dan Tempe

\begin{tabular}{ccc}
\hline $\begin{array}{c}\text { Penerimaan } \\
(\mathrm{Rp} / \text { bulan) }\end{array}$ & $\begin{array}{c}\text { Biaya produksi } \\
(\mathrm{Rp} / \text { bulan })\end{array}$ & $\begin{array}{c}\text { Nilai } \\
\text { R/C ratio }\end{array}$ \\
\hline $29.052 .000,00$ & $15.967 .701,39$ & 1,8 \\
\hline
\end{tabular}

Sumber: Data primer (diolah) 202

Tabel 8 menunjukan

penerimaan Rp. 29.052.000,00 per

bulan dan total biaya produksi sebesar Rp.15.967.701,39/bulan, sehingga menghasilkan nilai $\mathrm{R} / \mathrm{C}$ ratio sebesar 1,8. Nilai tersebut menunjukkan bahwa setiap kenaikan biaya Rp. 1,00, maka penerimaan akan naik sebesar 1,8 rupiah. Dengan demikian usaha 
tahu dan tempe di Desa Batu Timbau Kecamatan Batu Ampar Kabupaten Kutai Timur produktif atau menguntungkan sehingga layak untuk dikembangkan. Begitu juga hasil penelitian Porajuow dkk (2019) dengan hasil $\mathrm{R} / \mathrm{C}$ ratio sebesar 1,35 dan Febrinova (2020) mendapatkan hasil $\mathrm{R} / \mathrm{C}$ ratio sebesar 1,2, serta hasil penelitian Sulistianengsih dengan hasil $\mathrm{R} / \mathrm{C}$ ratio sebesar 1,76, sehingga usaha produksi tempe tahu layak dikembangkan. Hasil penelitian beberapa peneliti, bahwa usaha tahu tempe layak unuk dikembangkan. Sebagaimana juga dijelaskan oleh hasil penelitiam Naelis dan Novandra (2015), bahwa tingkat keuntungan usaha tempe sebesar 1,49, namun setelah kenaikan harga kedelai, tingkat keuntungannya hanya mempunyai nilai 1,19. Walaupun nilai $\mathrm{R} / \mathrm{C}$ rasio diatas 1 , namun menunjukkan tingkat keuntungan yang sangat kecil bahkan mendekati 1 .

$$
\text { Menurut Suratiyah }
$$
bahwa, apabila nilai $\mathrm{R} / \mathrm{C}$ ratio $>1$ maka usaha tersebut menguntungkan dan layak untuk dikembangkan. Dengan demikian usaha tahu dan tempe di Desa Batu Timbau Kecamatan Batu Ampar Kabupaten Kutai Timur produktif atau menguntungkan sehingga layak untuk dikembangkan lebih lanjut, karena memperoleh penerimaan yang cukup besar dan penggunaan biaya produksi cukup efisien untuk memproduksi tahu dan tempe. Untuk mempertahankan dan meningkatkan keuntungan sebaiknya usaha tahu dan tempe dapat menambah jumlah produksinya lebih banyak lagi serta memperkecil biaya produksi, dan menjaga kualitas cita rasa dari tahu dan tempe yang diproduksi.

\section{KESIMPULAN}

Berdasarkan penelitian yang telah dilakukan, maka dapat disimpulkan sebagai berikut:

1. Rata-rata biaya tetap usaha tahu dan tempe di Desa Batu Timbau sebesar Rp. 146.201,39 per bulan per pengusaha dan biaya variabel sebesar Rp.15.821.500,00 per bulan per pengusaha, sehingga dari perincian tersebut bisa diketahui total biaya produksi usaha tahu dan tempe di Desa Batu Timbau sebesar Rp.15.967.701,39 per bulan per pengusaha. Penerimaan usaha tahu dan tempe sebesar Rp.29.052.000,00 per bulan per pengusaha, dan pendapatan dari usaha tahu dan tempe sebesar Rp. 13.084.298,61/ bulan/pengusaha. 
2. Tingkat keuntungan usaha tahu dan tempe, diketahui penerimaan usaha adalah sebesar Rp.29.052.000,00 dengan total biaya produksi Rp. 15.967.701,39 sehingga didapat $\mathrm{R} / \mathrm{C}$ ratio 1,8. $\mathrm{R} / \mathrm{C}$ ratio bernilai lebih besar dari 1 maka dapat dikatakan bahwa usaha tahu dan tempe di Desa Batu Timbau adalah menguntungkan, sehingga layak untuk dikembangkan.

\section{DAFTAR PUSTAKA}

Anggraini, Prastiwi Dewi., Edy Prasetyo., Bambang Mulyatno Setiawan. 2016. Analisis Efisiensi Ekonomi dan Pendapatan Pengrajin Tempe di Kabupaten Klaten. Kesejahteraan Sosial Journal of Social Welfare Vol. 3 No. 2, September 2016: 155 - 171 ISSN: 2443-2016. http://trilogi.ac.id/journal/ks/inde x.php/jks

Ambara, K. Y., Ustriyana, I. N. G., Rantau, I. K. 2017. Profil Industri Kecil Tahu dan Tempe “Makmur Jaya" Di Kecamatan Denpasar Barat Kota Denpasar. E-Jurnal Agribisnis dan Agrowisata Vol. 6 No.2, April
2017.

http://ojs.unud.ac.id/index.p $\underline{\mathrm{hp} / \mathrm{JAA}}$

Amelia, R dan Astuti, A. 2018. Contribution Of Soya Tempe (Glycine max) Industrial Income Of Household Scale To Craftship Houshold Income In Soya Tempe (Glycine max) in Imogiri District, Bantul Regency. Jurnal Ilmiah Agritas. Vol. 2. No1. 2018. https://jurnal.ustjogja.ac.id/in dex.php/ agritas/issue/view/359

Anzitha, Silvia. 2019. Analisis Pendapatan Usaha Pembuatan Tempe dengan Tahu di Kota Langsa. Agrica (Jurnal Agribisnis Sumatera Utara) Vol.12 No.2/Oktober 2019. http://ojs.uma.ac.id/index.php/agr ica.

Djumadil, N. 2018. Analisis Kelayakan Usaha Pada Industri Tempe Sido Makmur di Kelurahan Cobodoe Kec. Tidore Timur Kota Tidore Kepulauan

Febrinova, R dan Gunawan, I. (2020). Studi Kelayakan Agroindustri Tempe Di Desa Kota Baru Kecamatan Kunto Darussalam Kabupaten Rokan Hulu 
Hairun, S, dan Zuraida, A. 2016. Analisis Usaha Pembuatan Tempe (Studi Kasus pada Usaha Pembuatan Tempe "Bapak Joko Sarwono") di Kelurahan Binuang Kecamatan Binuang Kabupaten Tapin. Jurnal Al Ulum Sains dan Teknologi Vol.2 No.1 Nopember 2016.

https://hellosehat.com/nutrisi/fakt a-gizi/tahu-dan-tempe-nutrisi/.

Diakses tanggal 1 Juni 2021.

Lestari W., Sumarjono, D dan Ekowati, E. 2019. SOCA: Jurnal Sosial Ekonomi Pertanian. Vol. 13 No. 3, 31 Desember 2019, page $409 \quad-\quad 419$. https://ojs.unud.ac.id/ind ex.php/soca

Naelis dan Novindra. 2015.

Analisis Ekonomi

Pengusaha Tempe

Dalam Menghadapi

Kenaikan Kedelai

Impor di Kelurahan

Semper Jakarta Utara.

Jurnal Agribisnis Indonesia

(Vol 3 No 2, Desember 2015);

halaman 97-112

Rondonuwu, A dan Sulaeman.

2018. Analisis Pendapatan dan Usaha Industri Tahu
Mitra Cemangi di Kota Palu.

J. Agrotekbis 6 (5): 717 - 723.

Rosita, A. H., Soelaiman, A. 2019. Analisis Usaha, Nilai Tambah, dan Kesempatan Kerja Agroindustri Tahu di Bandar Lampung

Sugiyono. 2012. Metode Penelitian

Kuantitatif, Kualitatif, dan R \& C. Alfabeta. Bandung.

Soehyono, F., Rochdiani, D., Yusuf, M.N. 2014. Analisis Usaha dan Milai Tambah Agroindustri Tempe (Suatu Kasus di Kelurahan Banjar Kecamatan Banjar Kota Banjar). Jurnal Ilmiah Mahasiswa Agroinfo Galuh Volume 1 Nomor 1, September 2014.

Suratiyah, K. 2015. Ilmu usahatani.

Penebar Swadaya. Jakarta.

Sulistianengsih, D., Rochdiani, D., Ramdan, M. 2017. Analisis Agroindustri Tempe (Studi Kasus Pada Seorang Perajin Tempe di Desa Sindanghayu Kecamatan Banjarsari Kabupaten Ciamis). Jurnal Ilmiah Mahasiswa Agroinfo Galuh. Volume 4 Nomor 2, Mei 2017.

Simatupang, D. I. S. 2019. Analisis Strategi Pemasaran Usaha Tempe 
di Kota Medan. Jurnal Ilmiah Skylandsea Vol. 3 N0.1. Februari 2019.

UU No. 3 Tahun 2014 UU 3 tahun 2014 tentang Perindustrian.

Wahyuni, D. 2017. Analisis Preferensi Agroindustri Tempe
Dalam Pemilihan Kedelai (Agroindustri Tempe Di Kota Tasikmalaya Kota Tasikmalaya). Jurnal Ilmiah Mahasiswa Agroinfo Galuh. Volume 4 Nomor 3, Sepetember 2017. 